\title{
A commentary on the Supreme Court's Judgment of 17 July 2018 (STS 1263/2018) and its supposed impact for a legally binding value of the decisions adopted by the Committee on the Elimination of Discrimination against Women (CED $\mathbf{W W}$ )
}

\author{
Eduardo JIMÉNEZPIXEDI
}

\begin{abstract}
Ibstract: The present contribution analy ses the Judgment of the Spanish Supreme Court of iz July 2or8. This judgment given by its Contentious- Administrative Chamber is thoroughly considered along the commentary, explaining the factual and procedural background of Ángela González’s claim consisting of the request of a compensation for the dramatic murder of her daughter by her ex-partner in a gender-violence context. Accordingty, after the exhaustion of local remedies, the appellant cleverly brought her claim before the Committee on the Elimination of Discrimination against Women, which adopted a decision recommending Spain to indemnify her for the damages suffered. Subsequently, on the basis of this favorable decision, the appellant sought a compensation for the State liability due to an abnormal functioning of the Administration of Justice, whose denial was appealed before the Supreme Court. Finally, the Supreme Court considered the CED AIV's decision as a "valid premise" to file a request of State liability and notably declared such decision as "legally binding obligatory" for Spain, although the CED AII's decisions have not that nature according to its Convention and Optional Protocol. As a result, the Supreme Court adjudged an economic reparation for the claimant and affirmed that Spain breached its international obligations. In brief, the commentary concludes with some reflections on the future implications that this arguable judgment of the Supreme Court may entail in relation to the international obligations of the State and the domestic enforeement of the decisions adopted by the CEI $\mathbf{I I}$ and by other $\mathrm{X}$ treaty bodies analogously.
\end{abstract}

Kevwords: CED AIV's decisions - Supreme Courl's Judgment, STS I263 $_{3} 2018$ - U X Treaty Bodies - breach of international obligations - human rights' enforcement

\section{(A) INTROI)LCTIO)}

The Supreme Court of Spain, by means of the Fourth Section of its Contentious- Administrative Chamber, delivered on 17 July 2018 its Judgment 12632018 in answer to the appeal made on behalf of Ángela González Carreño (Adelina along the judgment), in which -on the basis of the decision adopted by the Committee on the Elimination of Discrimination against Women- sentenced the Spanish State to indemnify the appellant as a consequence of the State liability, due to an abnormal functioning of the Idministration of Juslice, since her daughter was murdered by her ex-partner during a visiting

20 tricle published on 31 December 2019

PhD Candidate and Lecturer in Public International Law (FPU Scholarship awarded by the Spanish Ministry of Education, ref. FPU I6 o3/46), Universidad de Córdoba (eduardo.jimenez.pineda a uco.es) and, at the time of submitling this contribution, V isiting Scholar at The Dickson Poon School of Law at King's College London. The author would like to thank the editorial team and anonymous reviewers of the Spanish Yearbook of International Law for the invaluable opportunity and their helpful and fruitful feedback. All websites last accessed on g. July 2019 and translations by the author.

STS 1263/2018, 17 July 2018. 
arrangement in 2003.

First of all, the Committee on the Elimination of Discrimination against Women (hereinafter, the CED NII) is a United \ations treaty body that consists of 23 experts on women's rights. This Committee was established by the Convention on the Elimination of All Forms of Discrimination against Women (hereinafter, the Convention). ${ }^{2}$ Interestingly, this Convention prescribes, among other obligations, the States parties to submit regular reports to the Committee on how the rights (recognized by the Convention) are implemented.3 Besides, this Convention was amended by means of an Optional Protocol which enabled the CED NII, whether the State party has expressly accepted these procedures, to receive communications from individuals (or groups) submitting to the Commitlee claims of violations of rights protected under the Convention. Notably, both the Convention and the Optional Protocol entered into force for Spain on 4 February 198 , and 60 October 2001 respectively. 5

The Judgment object of this commentary swiftly became well-known because, on the one hand, it ended up a longjudicial process (over fifteen years) in a dramatic case of gender violence, and, on the other hand and more importantly for the purposes of this contribution, it recognized certain legally binding nature (even though, it is yet to be defined) to a decision which, in principle and as it will be argued, is not compulsory. As such, despite the judgment was delivered just one year ago, it has been already discussed by several scholars ${ }^{6}$. Moreover, this decision is the latest of a series of recent judgments given by the Supreme Court of Spain dealing with distinct Public International Law matters, some of which have been criticized by different authors as a result of the arguable approach to Public International Law carried out

\footnotetext{
2 Convention on the Elimination of All Forms of Discrimination against Women (adopted s 8 December I979, entered into force 3 September 1981) 1299 U NTS 13.

3 In order to ensure the protection of human rights and within the framework of the United Vations, there exist several councils and committees that act as mechanisms to monitor the accomplishment and implementation of human rights and have contributed to a certain institutionalization on this matter. Besides the CED AII, there are other human rights treaty bodies, although most of those mechanisms have a nature "more political than judicial", such as the Committee on the Elimination of Racial Discrimination (CERD), the Committee on Economic, Social and Cultural Rights (CESCR), the IIuman Rights Committee (IIRC), the Committee against Torture (C AT) or the Committee on the Rights of the Child (CRC).

4 Optional Protocol to the Convention on the Elimination of III Forms of I)iscrimination against IV omen (adopted 6 October r999, entered into force 22 December 2000) 213 U VTS 83.

5 Spain ratified the Convention on 18 December ig 83 and the Optional Protocol on 1/4 March 2000 (BOEno. 6g. 2 March 1984 and BOE no. Igo,g August 2001). See P. Durán y Lalaguna, "The CED NIV's Reception in Spain. The Gap between Law and Practice", g Yearbook on I/umanilarian Action and I/uman Rights (2011) 53-66, at 61 ss.

6 Among others, see: C. Escobar Hernández, Sobre la problemática determinación de los efectos jurídicos internos de los "dictámenes" adoptados por comités de derechos humanos. Algunas reflexiones a la luz de la STS I263,2018, de I7 de jullio",

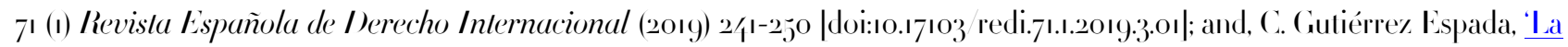
aplicación en España de los diclámenes de comités internacionales: la STS 1263, 2018, un importante punto de inflevión', 10 (2) Cuadernos de Derecho Transnacional (2018) 836-8 $3_{1}^{1}$ |doi:10.20318/edt.2018.41906|.
} 
by the Supreme Court. ${ }^{7}$

(1) Factual and procedural background

This case began by means of a request of State liability, filed by Ángela González, because of an "abnormal functioning of the Administration of Justice", seeking that its inadequate functioning caused the murder of her daughter by her former partner. This claim was brought taking into account that, according to Śngela, the murder could have been avoided whether the Administration of Justice would have correctly worked by keeping the visiting arrangements with surveillance established at a first moment. ${ }^{8}$ Vonetheless, this regime was modified by a later ruling which allowed the contact between the father and their daughter without surveillance. This last circumstance "determined" the murder of Ángela's daughter by her expartner on 2/ April 2003." In Ángela’s view, a high-risk situation existed, as proved by the 行 lawsuits that she lodged, and, in addition, the Public Prosecutor did not intervene in every legal proceedings, there were some mistakes in the social services' reports and, finally, some judicial decisions disregarded the psychological expert evidence. Such irregularities, if they would have not existed, would have avoided, in that high-risk situation, the murdered of Ángela's daughter." Consequently, in her view, there was an abnormal functioning of the Administration of Justice.

The aforesaid request of State liability was denied by a Ministry's resolution of 3 November 2005 and subsequently dismissed by the Vational Iligh Court's Judgment of to December 2oo8. Moreover, the Judgment of the National Itigh Court of to December 2008 was confirmed on 55 October 2016 by the Fourth Section of the Supreme Court's Contentious-Administrative Chamber (interestingly, the same section that rendered the Judgment object of the present contribution which, in the end, admitted this (claim). ${ }^{12}$

Vevertheless, the Vational Iligh Court's Judgment of to December 2008 was appealed by Ángela "in amparo before the Constitutional Court, alleging a violation of her constitutional rights to an effective remedy, to security, to life and physical and moral integrity, not be subjected to torture or cruel or degrading treatment or punishment, and to equality before the law". 3 The appeal was declared

7 See, for instance, M. García García-Revillo, Falta de jurisdicción de los tribunales españoles para conocer de delitos contra el medio ambiente (pesca IU U) comelidos por españoles mediante buques de pabellón extranjero en alta mar', 69 (2) Revisla Española de Derecho Inlernacional (2017) 345-351 |10.17103 redi.69.2.2017.3.02|; or, E. Jiménez Pineda, 'The Judgment of the Supreme Court sentencing Spain for failing to duly comply with the Council Decisions (EU) 2015 1 523 and 2015 I 60 on

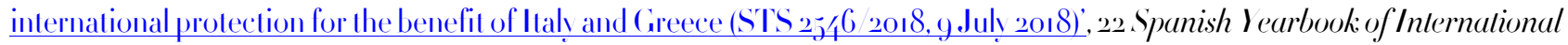
Law (2018) 439-4.5o |doi: 10.17103 sybil.22.23|.

$8 \quad$ STS $_{12} 63_{3} 2018$, supra n.I, Ihird legal basis (fundamenlo de Derecho).

9 Providencia, 6 May 2002.

10 STS 1263 2018, supra n.I, third legal basis.

" Ibid.

12 Ibid.

3. Communication \o. 47 2012, Decision of a 6 July 201/4 adopted by the Committee on the Elimination of Discrimination 
inadmissible on 3 April and iz June 20 m by the Constitutional Court as lacking" constitutional relevance".'1 This non-admission, understood as the exhaustion of local remedies, allowed Ángela to bring her claim to the CED AII in accordance with article 17 of the Convention on the Elimination of All Forms of Discrimination against $\mathbf{W}$ omen and, more specifically, article 4 ( I) of its Optional Protocol. ${ }^{5}$

Accordingly, the CED AII adopted its decision under article 7 of the Optional Protocol on the applicant's case on 16 July 201/4 declaring, among other considerations, that Spain "has infringed the rights of the author and her deceased daughter (...)". 'B Besides, the Committee made wo recommendations in the decision to Spain concerning the author of the communication, namely: "(i) grant the author appropriate reparation and comprehensive compensation commensurate with the seriousness of the infringement of her rights; (ii) Conduct an exhaustive and impartial investigation to determine whether there are failures in the State's structures and practices that have caused the author and her daughter to be deprived of protection”. ${ }^{7}$

On the basis of the Committee's views, the applicant, in order to enforee this "dictum" from the CED AII, brought before the Spanish State two different requests. ${ }^{8}$ Tonetheless, up until then, the effectiveness of the decisions given by the U X Treaty-based bodies, as professor Abril Stoffels pointed out, depended largely on the will of the States and hence the lack of willingness remained the major impediment of the CED AW's decisions."9 Consequently, professor Abril highlighted at that time being that "even if the CED AIV Committee determines that the State has failed to fulfil its obligations to CEDAII and recommends granting the author appropriate reparation and a comprehensive compensation, nothing can guarantee that these actions are finally implemented. As a matter of fact, this is what happened in Angelav. Spain case."

Firstly, Ángela filed an "extraordinary appeal for review" on i6 October 201/4 seeking the annulment of

\footnotetext{
against 11 omen at its fifty-eighth session (CED $11 \mathrm{C} / \mathrm{j}^{8}$ D)/47 2012), para. 2.21, italic emphasis in the original.

'1/ STS 12632018 , supra n.t, third legal basis.

15. The article iz of the Convention establishes in its paragraph one that "|l'|or the purpose of considering the progress made in the implementation of the present Convention, there shall be established a Commitlee on the Elimination of Discrimination against Women (hereinafter referred to as the Committee) consisting, at the time of entry into force of the Convention, of eighteen and, after ratification of or accession to the Convention by the thirty-fifth State Party, of twenty-three experts of high moral standing and competence in the field covered by the Convention. The experts shall be elected by States Parties from among their nationals and shall serve in their personal capacity, consideration being given to equitable geographical distribution and to the representation of the different forms of civilization as well as the principal legal systems".

The article / ( 1 of this Optional Protocolvery precisely provides that "|lthe Committee shall not consider a communication unless it has ascertained that all available domestic remedies have been exhausted unless the application of such remedies is unreasonably prolonged or unlikely to bring effective relief.". In the same vein, Rule j8 of the Rules of Procedure of The Committee on the Elimination of Discrimination Against Women reads as follows "ı. The Secretary-General may request clarification from the author of a communication, including: e) Steps taken by the author and or victim to exhaust domestic remedies", italic emphasis added.

16 Communication \o. 行 2012, supra n.13, para. 10.

17 Ibid, para. II, a).

18 STS $_{12} 63 / 2018$, supra n.I, third legal basis, $\left.\left.3^{\circ}\right), 1^{\mathrm{a}}\right)$.

19 R. Abril Stoffels, "The "effectiveness" of CED III Commiltee Decisions: Angela González Carreño v. Spain', 19 SYbIL (2015) $33^{6} 5^{-3} 372$, al 37 1 doi:10.17103 sybil.19.27|.

${ }_{20}$ Ibid.
} 
the previous Ministry's resolution of 3 November 2005 and likewise the enforcement of the dispositive part of the CED A W's Decision $47 / 2012$ by granting a comprehensive reparation, including a compensation of 1.263.470,09 euros. ${ }^{21}$ With regard to this first request, on 17 July 2015 Śngela received the administrative dismissal and afterwards appealed that decision whereby a contentious-administrative appeal, also dismissed by a Judgment of 25 April 2016 from the Contentious- Administrative Chamber of the National High Court. ${ }^{22}$ Subsequently, the plaintiff appealed the aforesaid decision before the Fourth Section of the Third Chamber of the Supreme Court, which finally rejected the appeal on 25 September $2017 .{ }^{23}$

Secondly, in parallel proceedings, on 6 February $20 y_{5}$ the applicant lodged a new request of State liability due to an abnormal functioning of the Administration of Justice. ${ }^{21}$ Throughout this request, Śngela sought the full reparation in accordance with the Communication No. 47/2012 adopted by the CED AII. This request was implicitly rejected, situation that enabled the claimant to bring a new contentious-administrative appeal, by means of a special procedure for the protection of fundamental rights, before the National IIigh Court, reaffirming the claim for the Spanish Administration to compensate her in the amount mentioned above. The third section of the contentious-administrative chamber of the National Iligh Court rejected again Ángela’s appeal by a Judgment given on 2 Xovember $2016 .^{26}$

Last but not least, Ángela appealed on 7 April 2017 that judgment before the ContentiousAdministrative Chamber of the Supreme Court, whose writ of 5 June 2017 finally admitted this case, triggering the proceedings that concluded in the Supreme Court's Judgment object of this commentary. ${ }^{27}$

In light of the above, a preliminary consideration can be mentioned concerning the various proceedings -bewilderingly described by the Supreme Court along the judgment- instituted on behalf of Śngela González in order to achieve a full reparation of the doubslessly serious and dramatic crime of their common daughter made by her ex-partner. Ilaving said that, the inarguable need of justice in form of compensation may have sidestepped the due respect of the domestic procedure, specially considering legal institutions as, among others, res judicata or abuse of process. In addition, this attempt to repair Ćngela's lost may have caused, in a nutshell and as it will be further explained, the possible overestimation of the legal value of the CED AIV's decision.

(2) Merits

The Fourth Section of the Contentious-Administrative Chamber of the Supreme Court analysed several aspects along the merits of its judgment. Thus, along the current section the most important of those aspects will be summarized on an attempt to identify the crucial elements of the judgment. The value given

\footnotetext{
${ }^{21} \mathrm{STS}_{12} 6_{3}$ 2018, supra n.t, third legal basis, $\left.\left.3^{\circ}\right), 1^{\mathrm{a}}\right)$.

$22 \quad$ S\ل

$23 \quad$ STS $34_{18} 8017,25$ September 2017.

24 STS 12632018 , supra n.1, third legal basis, $\left.\left.3^{\circ}\right), 2^{\mathrm{a}}\right)$.

-5 Ibid.

26 STS 12632018 , supra n.I, first and second facts (anlecedenles de hecho). See S1 1 /19j 2016,2 \ovember 2016.

${ }_{27}$ Ibid, third, fourth and fifth facts. See 1 TS $5786 / 2017,5$ June 2017.
} 
to the CED AIV's decision on Ángela's claim in order to adjudge the compensation is considered first and foremost.

\section{(a) Res judicala}

In order the Supreme Court to address the merits of the case, it firstly shall ensure the lack of a previous judgment about the identical facts and subject and on the same legal grounds. The assurance of the lack of this situation is specially significant in the present case taking into account the distinct procedures of different nature brought by Ángela González at both national (Administrative and judicial proceedings) and international levels (i.e. the CED III).

Accordingly, the National Iligh Courl's Judgment of 2 November 2016 appealed before the Supreme Court had declared that the request of a full compensation was the same that at the very beginning of the procedures (in 200/) but, interestingly, after the CED AIV's decision (in 201/), it is substantially based on such decision and therefore there was no identity in the terms of article 222.I Civil Procedural Act. ${ }^{28}$ As such, the exception of res judicata did not exist. In this regard, the Court asserted an unconventional argument, namely: "this tribunal, whilst deeply regrelling the deadly ending, does not find in the case at hand an abnormal functioning of the Administration of Justice."29

Once at the Supreme Court's appeal proceedings, the appellant, logically, adthered herself to the previous ruling on the lack of res judicata, even though adding objections on the other arguments given along the appealed decision. ${ }^{30}$ With regard to the State Administration view on res judicata, the State Attorney noted that "several judgments have been pronounced by Spanish tribunals denying the claim of a full compensation" and the real aim of the appellant was "to modify the final character of the judgment" in such a manner that "the legal institution of res judicata became inapplicable" 3r By the same token, the Public Prosecutor, alluding to the Judgment of the Constitutional Court 2/5 I99r of a December related to the domestic enforcement of the Judgments given by the European Court of Ituman Rights, ${ }^{32}$ contended that "the Convention |European Convention on I luman Rights| does not oblige to give internal effect to the European Court Judgments whereby the annulment of res judicata authority |...". ${ }^{33}$ Consequently, according to the Public Prosecutor, the same criteria should apply to the Convention on the Elimination of $\mathrm{All}$ Forms of Discrimination against $\mathrm{W}_{\text {omen. }}$

In light of the above, the Supreme Court, in examining the questions "object of cassation's interest" (sic) and by means of a very succinct statement, adjudged that the exception of res judicata does not apply in

28 Civil Procedural Act |LECiv|. Concretely, its article 222.I, intitled "material res judicata” (cosa juzgada malerial") establishes that: "the res judicata of the final and without appeal judgments, upheld or dismissed, shall exclude, in accordance with the law, a further proceeding whose object is identic to the object of the proceeding in which the judgment was given".

29 STS 12632018 , supra n.t, first legal basis, $\left.3^{\circ}\right)$, $2^{\circ}$ ). Precisely, the original words in Spanish mentioned by the court are: "este tribunal, aun lamenlando profundamente el falal desenlace, no aprecia que en el caso que nos ocupa existiese un funcionamiento anormal de la Administración de Justicia”, italic emphasis added both in the original and in the translation.

$3^{\circ} \quad$ Ibid, fourth legal basis, $2^{\text {a }}$.

$3^{3} \quad$ Ibid, fifth legal basis.

$3^{2} \quad$ STC2 2 1991, 16 December 1991.

33 STS $1263 / 2018$, supra n.ı, sivth legal basis. 
this case because of wo reasons: I) "it was refused in the appealed judgment and that decision has not been contested"; and, II) "the offence does not come exclusively from the facts decided at that time, but also from the actions and decisions of the Administrations in answering to those |facts|." ${ }^{34}$

\section{(b) The CED 1 II's communicalion no. 亿7 2012 González Carreño v. Spain}

(i) The admissibility of the submission: exhaustion of local remedies and miscarriage of justice

As mentioned before, the non-admission of the appeal on 13 April 20 by the Constitutional Court due to the lack of "constitutional relevance" entailed an exhaustion of local remedies that enabled Ángela to bring her claim before the Committee on the Elimination of Discrimination Against Women on the basis of articles 2, 5 and 16 of the Convention. ${ }^{35}$ Notwithstanding the unambiguous interpretation of article 4 ( ( ) of the Optional Protocol, in which accordance the CED AII shall not consider communications that have not exhausted "all available domestic remedies" with the sole exception of remedies "unreasonably prolonged or unlikely to bring effective relief", ${ }^{6}$ the main objections raised by Spain in the "process" at the CED 1 II were related to the inadmissibility of Ángela's claim because "domestic remedies had not been properly exhausted”. ${ }^{37}$

From the Spanish State perspective, the appropriate proceedings to achieve a full compensation for an abnormal functioning of the Administration of Justice was via the miscarriage of justice and not by virtue of the State liability $3^{8}$ In this sense, both procedures would be different: in order to obtain a reparation based on a miscarriage of justice, it is necessary a prior judgment which "expressively recognizes it”; while the reparation due to an abnormal functioning of the Administration of Justice does not require a previous judicial declaration as stated in article 292 of Spanish Organic Law on Judicial Power |LOPJ|. ${ }^{39}$ As such, according to the State Attorney, the murder "did not seem connected with an abnormal functioning of a court or its personnel”. ${ }^{\circ}$ Concerning other subsidiary arguments mentioned by the claimant, the State summarized that "no infringement of the Convention, particularly articles 2 and 5 , was committed since the Spanish authorities did not act negligently".'

Regarding the objections to the admissibility raised by Spain, Ángela's lawyers contended that her litigation was aimed to "show that there was a miscarriage of justice and not merely a judicial error". ${ }^{2}$ Votwithstanding the lack of an argument relating to the exhaustion of local remedies, the claimant

31 Ibid, seventh legal basis, third question, in fine.

35 See above p. 仡.

$3^{6}$ In this sense, International Justice Resource Center, "Exhaustion of Domestic Remedies in the I nited \ation Sistem", last updated August 2017.

37 Communication \o. 行 2012, supra n.13, para. 4.1. ss.

$3^{8} \quad$ Ibid, para. 4.2.

39 Ibid. Concretely, article 292 of the LOPJ establishes that "|d|amages caused to any assets or rights through judicial error, as well as those resulting from abnormal operation of the Administration of Justice, shall grant those who have suffered damage the right to compensation from the State, except in cases of force majeure, pursuant to the terms of this Title". Translation on the Communication \o. 行 2012.

10 Ibid, para. 1.6infine.

亿 Ibid, para. 仵.

1 $^{2}$ Ibid, para.. ... 
concluded her reasoning expressing her disagreement with the State's considerations and adding that the "version of events presented by the State party is distorted". 13.

In respect of admissibility and in view of the foregoing, the Committee firstly noted that "the same matter has not been and is not being examined under another procedure of international investigation or settlement”. 仡 Moving towards the main exception on admissibility, i.e. the exhaustion on internal remedies, which was indeed the only objection analysed by the CED XII, the Committee "must determine whether, in light of the Convention, the author exerted reasonable efforts to bring before national authorities her complaints regarding the violation of rights arising from the Convention”. In this sense, the Commitlee recalled that the author (sic) after the death of her daughter brought "several administrative and judicial appeals alleging miscarriage of justice on the part of the State", ${ }^{6}$ being all rejected. What is more, the appellant "filed an appeal in amparo before the Constitutional Court in which she alleged the violation of her fundamental rights |...|". To Therefore, taking into account that Spain had not pointed to other possible "legal avenues that could have been effective to respond to the specific and complete demands of the author, the Committee considers that internal remedies have been exhausted with regard to the complaint concerning the establishment by the authorities of an unsupervised visiting regime and the lack of redress for the negative consequences resulting from that regime". ${ }^{8}$ Thus, the Committee considered that the communication was admissible.

\section{(ii) The merits}

Once affirmed the admissibility of the communication, the Committee dealt with the merits of Ángela's claim. Briefly, the State Administration argued that the author of the communication did not mention any breach of the Convention along her cases before the Spanish tribunals. ${ }^{99}$ In addition, in spite of the complex familiar context and the tragical outcome, according to the State's position "Ithere was never a moment in which the child was not being monitored and watehed over by the social services under the court, always working in her interest"..$^{\circ}$ Moreover, the State provided a list of actions undertaken to eradicate all forms of discrimination against women since 1987 and also mentioned "activities carried out with a view to the training of justice system employees". ${ }^{5}$ On the other hand, the author of the communication contended to the State's observations on 9 August 2013 arguing mainly that "li|n order to discharge its duty of diligence, it is not enough for the State to adopt legislation on the subject; it is necessary for the legislation to be applied." $5^{2}$ Additionally, from Ángela’s perspective, the State party made

\footnotetext{
Ibid, para. 53 .

Ibid, para. 8.2.

Ibid, para. 8.6.

Ibid.

Ibid, italic emphasis in the original.

Ibid.

I) Ibid, para. 6.I.

;o Ibid, para. 6.j.

;I Ibid, paras. 6.6 and 6.7 respeclively.

$5^{2} \quad$ Ibid, para. 7.6.
} 
"no comment on the lack of a satisfactory assessment of the best interests of the child or the violation of her right to be heard in judicial proceedings".33 and, taking into account the reasons explained, requested the Committee to make several recommendations to Spain. ${ }^{51}$

The Committee started addressing the communication submitted to its considerations stating that the question was "that of the responsibility of the State for not having fulfilled its duty of diligence in connection with the events that led to the murder of the author's daughter" and averring that "the decisive factor is therefore whether those authorities applied principles of due diligence and took reasonable steps with a view to protecting the author and her daughter." In In this line, the Committee recalled that "these elements reflect a pattern of action which responds to a stereotyped conception of visiting rights based on formal equality which, in the present case, gave clear advantages to the father despite his abusive conduct and minimized the situation of mother and daughter as victims of violence, placing them in a vulnerable position. ${ }^{56}$

Notwithstanding that, as the Committee recalled, the authorities of Spain initially "took actions to protect the child in a context of domestic violence",57 it alluded to article 2 (a) of the Convention whereby States parties have the obligation "to ensure by law or other appropriate means the realization and practise of the principle of equality of men and women" ${ }^{8}{ }^{8}$ In the same vein, the CED XII noted that Ángela suffered "harm of the utmost seriousness and an irreparable injury as a result of the loss of her daughter" and that "her efforts to obtain redress have been futile." 59 Consequently, the Committee concluded that "the absence of reparations constitutes a violation by the State party of its obligations under article 2 (b) and (c) of the Convention”. Forthermore, the obligation to investigate the existence of failures, negligence or omissions on the part of public authorities was discharged too. ${ }^{61}$

Taking into consideration the foregoing, the Committee concluded that "the State party has infringed the rights of the author and her deceased daughter under articles 2 (a-f); 5 (a); and I 6 , paragraph I (d) of the Convention, read jointly with article s of the Convention and general recommendation No. rg of the

33 Ibid, para. $7 \cdot 7$.

3 The requested recommendations are the following: "(a) complete redress and or appropriate compensation, including, inter alia, payment with interest of unpaid child support; reimbursement with interest for the rent the author had to pay dur ing the three years she was denied use of the family dwelling; pecuniary and non-pecuniary costs; symbolic redress, including, inter alia, the creation of a fund in memory of Andrea for child viclims of domestic violence, tailored to organizations active in that field; (b) compensation to the author for physical and mental damages; (c) impartial and exhaustive investigation into the failures that occurred in implementing orders of protection, including ascertaining the responsibility of public officials; (d) public apology to the author for the failures in protecting her and her daughter; (e) impartial and exhaustive investigation into the failures that occurred regarding Andrea's right to be heard; (f) impartial and exhaustive investigation into the failures that occurred regarding the authorization of unsupervised visits. The author also asks that a recommendation be made to the State party to review its legislation on domestic violence, including aspects relating to the application of measures of protection, response to complaints of domestic violence and visiting and custody rights of an abusive parent”, Ibid, para. 7.8.
5. Ibid, para. 9.2.
$3^{6} \quad$ Ibid, para. 9. 4 .
37 Ibid, para. 9.j.
$5^{8} \quad$ Ibid, para. 9.7.
59 Ibid, para. 9.8.
Go Ibid.
6. Ibid, para. 9.9. 
Committee." ${ }^{62}$ As such, amongst other general recommendations, ${ }^{63}$ the Committee made two recommendations to the State party with regard to the author of the communication, namely: "(i) |g|rant the author appropriate reparation and comprehensive compensation commensurate with the seriousness of the infringement of her rights; (ii) conduct an exhaustive and impartial investigation to determine whether there are failures in the State's structures that have caused the author and her daughter to be deprived of protection"."

(c) Lack of a process to enforce the CEI) 1 II's decision

The pronouncement of a favourable decision to Ángela's claim by the CED AII on I6 July 2014 was cleverly used by the appellant before the Spanish courts and tribunals. Votably, this decision was the crucial element for the Supreme Court to admit the cassation appeal whereby a writ given on 5 June 2017. The crucial nature of CED AW's decision is reflected into the two questions with an "objective cassation's interest". First, which should be the appropriate process to request the Spanish State to enforce the CED IIV'S decisions. ${ }^{65}$ Second, whether the inexistence of a process in the Spanish legal system allowing to enforce those decisions did not entitle to seek autonomously the observance of the aforesaid decisions. ${ }^{66}$

Indeed, already the appealed judgment of the National Supreme Court of 2 November 2016 laid down that "it does not exist in the Spanish legal system a process that allows in this case the executive enforeement of the recommendations made in the CED AIV's decision". ${ }^{67}$ In this sense, the appellant, the State Attorney and the Public Prosecutor argued the lack of a process in Spain to enforce the decision of the Commitlee. In the first case, as an evidence of the abnormal functioning of the Administration of Justice, ${ }^{68}$ while, in the second and third cases, as a result of the lack of legally binding value of those decisions.

On this point, the State Administration denied the breach of the International Treaties because, even though they are legally binding for the State, "they do not contain any provision which affirms that the Decisions of the Committee of the CED $\mathbf{I I}$ are binding, mandatory and executive and article 7 of the

6.2 Ibid, para. 10.

6. In general, the Committee recommended to Spain as State party in the Convention and in the Optional Protocol to: "(i) |l|ake appropriate and effective measures so prior acts of domestic violence will be laken into consideration when determining custody and visitation rights regarding children and so that the exercise of custody or visiting rights will not endanger the safety of the victims of violence, including the children. The best interests of the child and the child's right to be heard nust prevail in all decisions taken in this regard; (ii) Strengthen application of the legal framework to ensure that the competent authorities exercise due diligence to respond appropriately to silualions of domestic violence; (iii) Provide mandalory training for judges and administrative personnel on the application of the legal framework with regard to combating domestic violence, including training on the definition of domestic violence and on gender stereotypes, as well as training with regard to the Convention, its Optional Protocol and the Commiltee's general recommendations, particularly general recommendation”, ibid, para. i2.

6 Ibid, para. 1 .

$6_{3}$ STS ${ }_{12} 632$ 2018, supra n.I, fourth fact. Concretely, the question originally in Spanish sars: "cuál debe ser el cauce adecuado para solicitar del Estado español el cumplimiento de los dictámenes del Comité de la CED III".

66. Ibid.

$6_{7}$ Ibid, lirst legal basis.

68 Ibid, fourth legal basis, $2^{\mathrm{a}}$ ). 
Protocol just confers the faculty of transmilting "views" and "recommendations"”." ${ }^{69}$ Likewise, in the Public Prosecutor's understanding there is no specific and autonomous process to seek the fulfilment of CED AIV's decisions, denying that "the international texts invoked allow to affirm the hypothetical existence of a breach of the international obligations, even recognizing the responsibility in relation to a citizen, entails automatically the existence of a subjective right of the citizen that entitles to seek with immediate executive effect the individual enforcement". $7^{\circ}$

Remarkably, the Supreme Court summarized the lack of a domestic process to enforce the CED III's decision when it dealt with the second legal question of cassation's interest declaring that "there is a clear conformity between the parties about the fact that according to the international norms and the domestic law adduced, there is not a specific and autonomous process in order to request the enforcement of the CED III's decisions." ${ }^{71}$

\section{(d) Main questions of cassalion’s inleresl}

As a consequence of the previous conclusion, the Supreme Court deduced that the essential question to determine was whether the process of State liability claim due to an abnormal functioning of the Administration of Justice is or not appropriate to achieve an administrative decision which allows the enforcement of the Decision $47 / 2012$ given by the CED $1 \mathrm{~W} .7^{2}$

In this regard, the Court "gives a positive answer" to the nature of the Committee's decision as a premise in order to file a request of State liability taking into account, in short, the following considerations. ${ }^{73}$ Firstly, although the Convention has not introduced in the domestic legal system a higher supranational institution and even though neither the Convention nor the Protocol establish the execulive nature of CED AIV's decisions, "there cannot be doubt that they will have binding obligatory value for the State party which recognized the Convention and the Protocol since article 2/4 of the Convention stipulates that "States Parties undertake to adopt all necessary measures at the national level aimed at achieving the full realization of the rights recognized in the present Convention" "."

Secondly, the decision is rendered by a "body created within the international legistation that, by express stipulation in article 9.6 of the Spanish Constitution, belongs to our domestic legal system” and

69 Ibid, lifith legal basis.

7o Ibid, sixlh legal basis.

7 Ibid, seventh legal basis, second question.

$7^{2}$ Ibid, seventh legal basis, third question.

73 Ibid. Exactly, the words in Spanish of this ratio decidendi were: "es esencial determinar si el Dictamen del Comité de la CED NII, por su propia naturaleza, puede ser, en sentido amplio, el presupuesto que permita formular esa reclamación de responsabilidad patrimonial. Daremos una respuesta positiva en función de las siguientes consideraciones".

7t Ibid. Similarly, the Supreme Court recalled in the judgment that according to article 7.4 of the Optional Protocol "Ithe State Party shall give due consideration to the views of the Committee, together with its recommendations, if ans, and shall submit to the Committee, within six months, a written response, including information on any action taken in the light of the views and recommendations of the Committee", emphasized by the express acknowledgment of the CED AIV's competence by means of article s of the Optional Protocol, voluntarils accepted by Spain. This article one establishes that "|al State Parts to the present Protocol ("State Parts") recognizes the compelence of the Commillee on the Elimination of Discrimination aggainst It omen ("the Committee") to receive and consider communications submitted in accordance with article 2 ", italic emphasis added. 
additionally "as a result of article 10.2 of our Constitution, the norms related to fundamental rights will be interpreted in accordance with the Universal Declaration of Human Rights and the treaties and international agreements about those subjects ratified by Spain"7.5

Thirdly, according to the Supreme Court, "there is no obstacle for the violation of several rights recognized by the Convention and declared by the decision of the CED AII to |... be a determinant element in order to prove violation of the fundamental rights of the appellant" since those treaties and international agreements are "also hermeneutic instruments of the fundamental rights of the Spanish Constitution according to its article 10.2".$^{-6}$

Fourthly, the CED IW's declaration "binding for Spain as a State party which has recognized |... the competence of the Committee ex article s of the Optional Protocol |..." implies the violation of the rights recognized in the Convention "which is referred to a universal legal principle recognized by several international texts such as the Convention, the Universal Declaration of Human Rights of i9/4 -article 7-, the Rome Convention for the Protection of Ituman Rights and Fundamental Freedoms of r95o -article I/- and the Charter of Fundamental Rights of the European Union -article 21-" 77

Fifthly, and importantly, "the CED AIV's decision must be considered, in this case and with its particularities, as a valid prerequisite in order to lodge a State liability request regardless of the previously denied one" ${ }^{8}$ Finally, the Supreme Court declared regarding the third question of cassation's interest that neither the exception of res judicata nor the principle of legal certainty do apply with regards to the first judgment denying the liability because the current judgment "is not reviewing or declaring invalid those administrative and judicial decisions, but instead recognizing the existence of a different premise" ${ }^{79}$

The fourth and last question of cassation interest consisted of the affirmation whereby "international law and international obligations acquired by Spain are Law that the State, as a rule of law democratic State, shall respect and effectively apply in a manner that the rights and freedoms, proclaimed in the Constitution and the international treaties concluded by Spain, are real and concreted". ${ }^{80}$ Thus, the Supreme Court considered the lack of a specific process to enforce the decisions of the Committee "in itself as a breach of a legal and constitutional obligation", highlighting the tribunal the special relevance of dealingwith a special process for the protection of fundamental rights. ${ }^{8}$ Consequently, the Supreme Court

75 Ibid. In this sense, the previous find of the tribunal has a special relevance because there is a claim of a breach of fundamental rights based on the declaration made by the international bods recognized by Spain, "the declaration of the international body has been made within the framework of an expressly regulated due process with the full participation of Spain", and, due to article 9:3 of the Spanish Constitution, "international obligations related to the enforcement of the decisions of international bodies of control whose competence has been accepted by Spain belong to our domestic legal system", ibid.

$7^{6}$ Ibid.

77 Ibid. On this point, the court considered that the violation was in relation to both article 1 / of the Spanish Constitution right to equality and non-discrimination on grounds of gender- and its article 2/ -right to an effective remedy-and also to its article $y_{5}$-right to respect moral integrity-.

$7^{8}$ Ibid. For a domestic law perspective in this regard, see M. López Benílez, 'U na aproximación a la normativa sobre violencia de género desde el Derecho administrativo’, 50 Revisla General de Derecho Administralivo (2019) 1-40, at 33.

79 STS 12632018 , supra n. I, seventh legal basis, third question.

8o Ibid, seventh legal basis, fourth question.

81 Ibid. 
affirmed that the Administration violated the fundamental rights of the appellant and did not implement the CED AIV's decision, to which it was obliged under the terms set out in the Convention and in the Optional Protocol. As a result, the Court declared null and void both the appeal judgment and the administrative decision and, as well, it determined the obligation to repair such violation. ${ }^{{ }_{2}} \mathrm{~W}$ ith the aim of achieving this last purpose, the Court fixed a compensation of 6oo.ooo euros, being that quantity almost the half of the reparation requested by the appellant but, according to the Court, a "sufficient and proportionate amount." ${ }^{83}$

\section{(3) Conclusion of the Supreme Court}

In light of the above, the Supreme Court declared that: (I) the inexistence of a specific and autonomous process to enforee into the Spanish legal system the recommendations of a CED IIV's decision hampers the autonomous request of the enforcement of those decisions; (2) despite the lack of an appropriate process, it is possible to admit this decision as an enabling premise to lodge a State liability's request; and (3) the Administration violated the appellant's fundamental rights. ${ }^{8}$ Therefore, the Supreme Court by settling the cassation appeal: (I) adjudged that the appeal (filed on behalf of Ángela against the Judgment rendered on 2 November 2016 by the third section of the Contentious-Administrative Chamber of the Vational Iligh Court) was plausible and nullified that 2016 Judgment; (2) partially upheld the contentiousadministrative appeal, condemning the Administration to compensate in the amount of 6oo.ooo euros because of the moral damages suffered by Ángela; and (3) did not to assign the cost of the appeal. ${ }^{8.5}$

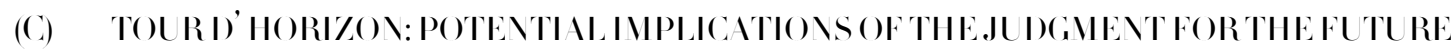

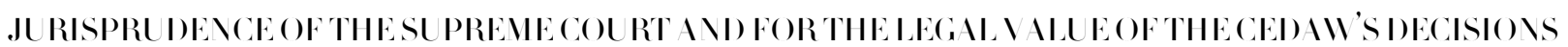

Article ı.6 of the Spanish Civil Code |Cc| establishes that "the jurisprudence will complement the legal system with the doctrine that, in a reiterated manner, is established by the Supreme Court in interpreting and applying the law, the costume and the general principles of law." ${ }^{86}$ In this sense, the general interpretation traditionally given by scholars and practitioners to this provision results in the understanding that there is jurisprudence from the Supreme Court-able to complement the legal sy stemas soon as there are two judgments applying the same interpretation to a certain law. Therefore, and at least in principle, the Judgment commented along this article does not "create" jurisprudence, even though a further judgment of the Supreme Court carrying out the same interpretation would trigger the consideration of this interpretation as jurisprudence. Vevertheless, the potential impact and influence for

$8_{2} \quad$ Ibid.

$8_{3} \quad$ Ibid. See above p. j.

8, Ibid, eighth legal basis.

8. STS $_{1263} 2018$, supra n. I, decision (fallo).

86 The original version of the Cc in Spanish reads as follows: "La jurisprudencia complementará el ordenamiento jurídico con la doctrina que, de modo reiterado, establezca el Tribunal Supremo al interpretar y aplicar la ley, la costumbre y los principios generales del derecho". Nonetheless, the legal debate about the concept of jurisprudence exceeds the scope of this article. 
future cases of the interpretation given by the Supreme Court to the CED IIV's decision are doubtless. In any case, the effects of the judgment are final and binding concerning Ángela’s claim.

It first glance, as professor Concepción Escobar pointed out, the nature and effects vis-à-vis the public authorities (of the decisions of the international bodies for the protection of human rights) have been object of a permanent debate both in the doctrine and in the jurisprudence. ${ }^{87}$ In a nutshell, the answer to that dilemma "has been neither clear nor uniform, having a hard practorian component" and "based on individual solutions, effective exclusively on a case-by-case basis". ${ }^{8}$ In this regard, there has been just one constant element, i.e., the doctrine of the Constitutional Court about the meaning of article ro.2 of the Spanish Constitution and, as professor Escobar upholds, the special hermeneutic effect of the international treaties about human rights in order to define the essential content of the constitutionally recognized rights. Unlike the Constitutional Court, the Supreme Court had been so far reluctant to recognize that the decisions of the international bodies for the protection of human rights may have any effect into the Spanish legal system. ${ }^{89}$ The previous assertion, logically, until the Supreme Court's Judgment on Ángela's case of July 2018, which has been rightly defined by professor Escobar as a "Copernican revolution" 9"

In principle, the decisions given by the CED III (initiated by a communication as in the case of Ángela's claim) shall be brought before the attention of the State party concerned and "within six months, the receiving State Party shall submit to the Committee written explanations or statements clarifying the matter and the remedy, if any, that may have been provided by that State Party" ." However, the process within the Committee initiated by a communication, logically, must not be understood as a contradictory process before a court plenty of guarantees..$^{22}$ Although, the Supreme Court is paradoxically implementing in this case a decision arising from the communication process before the CED $\mathbf{I I}$ as an appropriate premise with an obligatory legally binding value. In this sense, it could be envisaged under the reasoning of the Supreme Court, in addition to the desire of ruling justice, the understanding of these "procedures" as authentic judicial proceedings before a court sensu stricto. In any case, the legal effects of the CED AIV's decisions, even if they cannot be considered binding, must be analysed at least from a hermeneutic perspective, regardless of whether such interpretation is or not an "authentic interpretation". 93

Taking into consideration the number of $\mathrm{U}$ X bodies for the protection of human rights, as professor Casla pointed out, "raising the legal weight of UX decisions on individual complaints could lead to a greater use of this redress mechanism." ${ }^{91}$ On this point, this author gave the example of the Government

${ }_{7}$ C. Escobar Mernández, supra n.2, at 2 亿3.

88 Ibid.

89 Ibid, p. 2作.

$9^{\circ}$ Ibid.

9r Article 6 (2) of the Optional Protocol.

92 See C. O'Rourke, 'Bridging the enforcement gap.' Evaluating the inquiry procedure of the CEI) III Optional Protocol', 27 (1) American I niversily. Journal of Gender, Social Policy and the Law (2019) 1-30, at / ss.

93 C. Escobar Hernández, supra n.2, al 2/18.

91 K. Casla, 'Supreme Court of Spain: U \ Treats Bodv individual decisions are legall binding', E.JIL Talk:', published on 
of the United Kingdom that justified the rejection of several recommendations adopted by the Universal Periodic Review declaring (regarding the Optional Protocols) that "the U I process is not an appeal mechanism, it cannot reverse decisions of the domestic courts, and it cannot result in an en forceable award of compensation for the applicant." ${ }^{95}$ For these reasons, according to professor Casla, with whom I agree, “jurisprudential turn would take this excuse away from governments and could lead to more international cases from lawyers and claimants. ${ }^{96}$

\section{(I) COXCLUSIO)}

The judgment of the Supreme Court commented along this contribution implies a revolutionary decision not only for Spain but also for comparative Constitutional Law and International Law of Ituman Rights. What is more, this judgment is the latest of a series of sentences -given by the Spanish Supreme Courtdealing with different fields of Public International Law whose approach is at least controversial.

To sum up, the revolutionary element of this judgment is found on its main ratio decidendi since the Supreme Court considered a decision adopted by the Committee on the Elimination of the Violence Against Women as a "valid premise" to file a request of State liability. As such, the Supreme Court understood the aforesaid CED NIN's decision as a new element that enabled the Court to admit an appeal in cassation and likewise to overcome the procedural obstacle of the res judicata, given the fact that there were several judicial decisions with the triple identity of subject, object and legal basis. Moreover, the decision of the Committee is deemed by the Court along its judgment as "legally binding obligatory" for Spain as the State party which recognized (sic) the Convention and the Optional Protocol.

Importantly, the claim brought on behalf of the appellant is undeniably legitimate, specially taking into consideration the dramatic crime suffered by Ángela in the person of her daughter, who was terribly murdered by Ángela's ex-partner. In this sense, the legal strategy carried out by her lawyers was finally successful, after several administrative requests and different lawsuits and appeals before the highest Spanish judicial institutions. In the same vein, the step bringing her claim before a U I treaty body committee shows the special commitment with Ángela's case while a noteworthy legal knowledge, without thereby existing an abuse of proceedings. In this context, it seems that this will (and even this need) to do justice is behind the verdict of the Supreme Court, as the obiter dictum "whilst deeply regretling the deadly ending" present in previous judgments of the National I ligh Court apparently reflects.

Vever theless, the comprehensible wish of justice to compensate the appellant for the damages suffered shall under no circumstances justify a judicial decision which in somehow exceeds the legal sy stem. In my opinion, the interpretation of the value of the CED IIV's decisions may be risky since it forces the State to accept and apply domestically certain obligations in respect of which the State has not been committed internationally. By the same token, the ruling of the Supreme Court seemingly misunderstands the nature

\footnotetext{
I August 2018.

95 Ibid.

$9^{6}$ Ibid.
} 
of the Committee considering that, as a U $\backslash$ treaty body, its essence is political and not judicial. Last but not least, the existence of several U I committees for the protection of human rights, able to adopt decisions about the enforeement of human rights according to its respective treaty, distrusts even more the approach taken by the Supreme Court, considering the likely hazard for the legal certainty and the hypothetical opening of a "new appeal proceeding". Moreover, even though the CED AIV's decisions have not, according to its Treaty and Optional Protocol, legally binding value, sight should not be lost, as noted by professor Escobar, that, on the one hand, those decisions may (and indeed) have legal effects from a hermeneutic perspective, conclusion that is in line with article to.2 of the Spanish Constitution. On the other hand, this judgment answers to the particular circumstances of the case and its findings must not be extended to another siluation.

Finally, this author would not like to end these lines without standing up for the Supreme Court, whose judgment in this case -in spite of its inconsistent approach- clearly answers to the need of implementing in the Spanish legal system the treaties of human rights in which Spain is party. Thus, in order to confirm whether the Supreme Court upholds the particular approach carried out in this case or it modifies this interpretation, scholars and practitioners must expectantly but patiently wait for the following judgment of the Supreme Court dealing with a decision adopted by the CED III (or by another U I treaty body). In the meanwhile, international lawyers may keep debating about whether the ratification by the Supreme Court of this "incipient jurisprudence" would open the floodgates or, conversely, it would imply a further step in the international protection and enforcement of human rights. 